always made a vicious onslaught at me, so I wore a heavy overcoat, a cap pulled well down over my ears and a pair of buckskin mitts. I took it all as a friendly joke and he always finished up by cursing me heartily in an exceedingly high voice.

Their pen was just by the house and I passed and spoke to them every time I went to the barn. I learned their language and they talked back to me. I became so adept in their language that you couldn't tell which of us was talking.

During the winter I placed them in the hen-house. I hung their cans up cut of reach of the hens. They lived in perfect peace with both hens and roosters. The hen-house was made of logs, chinked with mud. They pierced holes through the mud and stuck their heads through and carried on a conversation with me every time I crossed the yard. They wintered very well. Occasionally I let them out for an hour or two and they were quite easily herded back in.

The third spring the female laid cne egg, but they made no attempt to incubate it. The fourth summer they incubated one egg and it hatched normally. They didn't know how to feed it. I provided boiled egg and milk and everything I had, but on the seventh morning it was dead.

That fall I built a new wooden hen-house. I didn't know enough to provide air holes for the cranes. They contracted tuberculosis and died in April. I had had these cranes for nearly four years.

My Sandhill Cranes remained healthy on a very simple diet. I think that Sandhills could be raised successfuly at very little expense and with not too much trouble.

\section{Raising Cranes in the San Antonio Zoo}

Mr. Fred W. Stark, director of the San Antonio Zoo in Texas, tells in the GAZETTE, April 1957, of his experiences in raising 22 cranes in San Antonio. His young birds are fed on a "wide variety of foods, such as raw meat, fish, shrimp, hard-boiled eggs, turkey mash, and many other things." He says that these birds will develop rickets if they are given a diet high in minerals. Yo birds that were raised artifici were always started on meal wo and no difficulty was experier in bringing them through to $\mathrm{ma}$ ity.

Cranes in the San Antonio Zoo not lay eggs until they were years old. The 22 cranes raisec the zoo include nineteen $S$ Cranes, two Crown Cranes and little Lilford Crane. Some of $t$ birds were raised by their par but others were raised artifici Mr. Stark says, "We do know by removing the eggs from cr breeding in captivity, they sometimes lay as many as six ti If this could be done with Whoo Cranes, it would certainly give a chance to increase the flock $w$ it would not face the problem of ing extinct."

Mr. Stark reports that the Manchurian Crane, so similar to Whooping Crane, has been ró successfully in the Honolulu Zoo in the Munich Zoo.

\section{Information on Cran Wanted}

Mr. Fred Bard, Director of Saskatchewan Museum of $\mathrm{Na}$ History, is anxious to compile tribution and migration data Sandhill Cranes. If you knov feeding or roosting or ne areas, please send the informatic the Museum, Regina.

Sandhill Cranes begin arrivir Saskatchewan about April 5. Us they have areas of preference $x$ they congregate to roost for night and feed in nearby fields earliest cranes to arrive will perse and travel to their $n \in$ in grounds. The last to arrive fron th south will move on further nor nest to the limit of suitable These are generally considered the Lesser Sandhills. It is impo: in the field to distinguish bet ee these northern Sandhills and bu southern cranes that nest in th muskegs of our forested region: 